\title{
PEMANFAATAN APLIKASI YOU TUBE DAN TIK TOK DALAM PEMBELAJARAN SENI BUDAYA SELAMA PANDEMI PADA MATERI BERKREASI SENI TARI
}

\section{CHANDRA AYU PROBORINI}

SMA Negeri 1 Kencong Jember

e-mail: chaproborini@gmail.com

\begin{abstract}
ABSTRAK
Selama masa pandemi pemerintah memberikan kebijakan bahwa proses pembelajaran harus dilakukan dengan dengan jarak jauh. Hal ini menjadi sebuah permasalahan bagi guru seni budaya dalam melakukan proses pembelajarannya. Pembelajaran seni budaya membutuhkan kegiatan apresiasi dan ekspresi dalam proses pembelajarannya, sehingga apabila pembelajaran dilakukan secara PJJ, maka akan mengurangi minat siswa dan ketercapaian indikator yang sudah ditentukan. Adanya permasalahan tersebut membuat guru harus merubah strategi dalam proses pembelajarannya agar indikator tetap dapat tercapai. Adapun dengan memanfaatkan aplikasi You Tube dan Tik Tok yang di kemas dengan model pembelajaran Problem Based Learning (PBL) dapat menjadi solusi yang baik, dimana aplikasi Youtube sebagai pengganti media berapresiasi dan aplikasi Tik Tok sbagai pengganti media dalam berekspresi. Berdasarkan latar belakang yang diungkapkan penelitian ini akan membahas tentang pemanfaatan aplikasi You Tube dan Tik Tok pada proses pembelajaran seni budaya materi berkreasi tari. Penelitian ini bertujuan untuk mendeskripsikan bagaimana pemanfaatan aplikasi You Tube dan Tik Tok pada proses pembelajaran seni budaya materi berkreasi tari. Penelitian ini menggunakan pendekatan deskriptif kualitatif. Pengumpulan data dilakukan dengan studi lapangan yaitu teknik observasi, dan studi dokumentasi, sedangkan studi data dilakukan dengan 3 tahap yaitu reduksi data, penyajian data, dan penarikan kesimpulan. Adanya penelitian ini diharapkan dapat menginspirasi para guru agar selalu berinovasi dalam proses pembelajaran, karena hasil penelitian ini dapat mendeskripsikan bahwa dengan memanfaatkan aplikasi You Tube dan Tik Tok pembelajaran menjadi lebih menyenangkan dan dapat mencapai indikator yang sudah di tentukan.
\end{abstract}

Kata Kunci: You Tube, Tik Tok, Pandemi, Berkreasi Seni Tari.

ABSTRACT

During the pandemic, the government gave a policy that the learning process must be carried out remotely. This becomes a problem for art and culture teachers in carrying out their learning process. Cultural arts learning requires appreciation and expression activities in the learning process, so that if learning is carried out in PJJ, it will reduce student interest and achievement of predetermined indicators. The existence of these problems makes teachers have to change strategies in the learning process so that indicators can still be achieved. Meanwhile, utilizing the You Tube and Tik Tok applications packaged with Problem Based Learning (PBL) learning models can be a good solution, where the Youtube application is a substitute for appreciative media and the Tik Tok application is a substitute for media in expression. Based on the background revealed, this study will discuss the use of You Tube and Tik Tok applications in the art and culture learning process for creating dance materials. This study aims to describe how the use of You Tube and Tik Tok applications in the art and culture learning process for creating dance materials. This research use desciptive qualitative approach. Data collection was carried out by field studies, namely observation techniques, and documentation studies, while data studies were carried out in 3 stages, namely data reduction, data presentation, and drawing conclusions. This research is expected to inspire teachers to always innovate in the learning process, because the results of this study can describe that by utilizing the You Tube and Tik Tok applications learning becomes more fun and can achieve predetermined indicators.

Keywords: You Tube, Tik Tok, Pandemic, Creative Dance. 


\section{PENDAHULUAN}

Pandemi Covid-19 memberikan dampak yang besar pada dunia pendidikan di Indonesia, dampak tersebut salah satunya pada sistem pendidikan di Indonesia. Perubahan sistem pendidikan tersebut disebabkan dengan adanya kebijakan pemerintah mengenai kewajiban setiap sekolah untuk melaksanakan sistem Pembelajaran Jarak Jauh (PJJ). Adanya PJJ membuat seluruh stakeholder sekolah, salah satunya guru diharuskan merubah strategi dan media pembelajaran dalam menyikapi situasi dan kondisi pada saat pandemi. Perubahan strategi dan media pembelajaran tersebut, tentunya bertujuan agar proses belajar mengajar dengan siswa tetap berjalan secara maksimal sehingga indikator pembelajaran dapat tercapai. Dalam hal menyusun strategi dan media pembelajaran salah satu yang dapat membantu guru dan siswa adalah pemanfaatan teknologi informasi secara maksimal. Adapun hal tersebut secara tidak sengaja memaksa guru agar lebih melek digital dan menguasai teknologi informasi dalam menunjang proses belajar mengajar bersama siswa.

Mengahadapi masa pandemi seperti saat ini, seorang guru dituntut harus menguasai teknologi informasi. Dengan meguasai teknologi informasi maka proses adaptasi di masa pandemi akan menjadi mudah dan dinamis (Fanaqi, 2021). Hal ini harus dilakukan demi tercapainya target indikator dalam pembelajaran, adapun dalam artikel ini adalah proses pembelajaran Seni Budaya. Dalam pembelajaran seni budaya terdapat dua aktivitas yang harus dilakukan yaitu apresiasi dan ekspresi. Kedua aktivitas tersebut tentu membutuhkan strategi dan media baru dalam proses pembelajarannya. Tentu hal ini menjadi permasalahan bagi guru seni budaya, yang semula materi ekspresi (kegiatan praktek seni) dilakukan di kelas dengan tatap muka tetapi di paksa harus dari rumah. Selain guru harus mahir dan mengusai teknologi informasi, guru seni budaya juga harus kreatif dan inovatif dalam menyusun strategi dan media pembelajarannya. Hal ini bertujuan untuk menarik minat para siswa dalam pembelajaran seni budaya dengan sistem PJJ. Selain itu hal tersebut dapat memberikan stimulus kepada siswa bahwa mereka tetap dapat berapresiasi dan berkeskpresi walaupun dari rumah.

Adanya perkembangan teknologi dan informasi menjadi sebuah solusi dalam beraktivitas selama masa pandemi Covid-19. Sesuai dengan survey yang dilakukan oleh Kominfo, pengguna internet Indonesia pada tahun 2020 berjumlah 73,7 persen, naik dari 64,8 persen dari tahun 2018 (Kominfo : 2020). Teknologi informasi bergeser menjadi sebuah kebutuhan primer dalam kehidupan sehari-hari karena kebutuhan beraktivitas dari rumah, dalam hal ini adalah bekerja bagi guru dan aktivitas sekolah bagi siswa. Teknologi informasi ini dapat membantu dengan maksimal proses pembelajaran bagi guru dan siswa, apabila dimanfaat dengan baik secara kreatif dan inovatif. Seorang guru harus peka dengan perkembangan teknologi informasi yang terjadi. Seperti halnya perkembangan media sosial yang populer di kalangan generasi muda tidak terkecuali siswa pada tingkat sekolah menengah. Populernya media sosial dapat menjadi peluang bagi guru dalam memanfaatkannya ke dalam proses pembelajaran dengan sistem PJJ, seperti halnya aplikasi You Tube dan Tik Tok. Media sosial menjadi sebuah kebutuhan primer bagi lembaga sekolah karena dapat membantu dalam berbagai aspek (Kaplan, 2010). You Tube dan Tik Tok merupakan aplikasi kekinian dan populer dikalangan siswa sekolah menengah, tentunya selain membantu lebih efektif bagi guru dan sekolah, hal ini akan sangat menarik minat siswa apabila aplikasi tersebut dimanfaatkan dalam proses pembelajaran Seni Budaya. Pemanfaatan aplikasi Youtube dan Tik Tok sangat diperlukan dalam pembelajaran seni budaya yang mempunyai dua ranah yaitu, apresiasi dan ekspresi. Aplikasi Youtube sebagai alat bagi guru dalam menyampaikan materi dan sebagai media apresiasi bagi siswa. Sedangkan aplikasi Tik Tok sebagai media ekspresi bagi siswa.

Meskipun guru selama pandemi pembelajaran yang dilakukan dibantu dengan teknologi dan informasi, akan tetapi hal ini tidak menjamin dalam keberhasilan proses belajar mengajar siswa dan guru. Selama pandemi banyak sekali indikator-indikator yang tidak tercapai, sehingga siswa hanya menerima sebuah pemaparan tanpa mempelajari lebih dalam. Dalam pembelajaran seni budaya siswa hanya melakukan ranah apresiasi, tanpa melakukan ekspresi. Hal ini menyebabkan peroses poembelajaran tidak berjalan maksimal, karena dalam 
pembelajaran seni budaya harus mencakup dua ranah yaitu apresiasi dan ekspresi. Apresiasi sebagai media pendalamn teori seni budaya, sedangkan ekspresi sebagai media siswa dalam berkarya seni dengan melakukan praktek. Oleh karena itu sangtalah dibutuhkan sebuah inovasi yang dapat mewadahi dua ranah tersebut, sehingga indikator yang di tentukan oleh guru seni budaya dapat tercapai.

Pada penelitian sebelumnya yang tulis oleh Lurita Sari tentang peningkatan kualitas pendidikan melalui aplikasi Youtube, menjelaskan bahwa Aplikasi Youtube sangat menarik minat para siswa. Youtube merupakan aplikasi yang dapat diakses dimana saja secara gratis dan dapat di putar berulang-ulang apabila merasa kurang paham dengan materi yang disampaiakan melalui video Youtube (Sari, 2020). Selain itu dalam penelitian lain tentang Tik Tok sebagai media kreativitas juga dijelaskan bahwa Aplikasi Tik Tok dapat menunjang aspek indikator kreativitas yaitu kelancaran dalam berfikir, keluwesan dalam berfikir dan proses pengembangan gagasan/ide. Dalam penelitian ini juga dijelaskan bagaimana Tik Tok dapat mengusir kebosanan seseorang pada masa pandemi yang mangharuskan berkativitas dari rumah (Fanaqi, 2021).

Berdasarkan pemaparan di atas maka dalam artikel ini akan mendeskripsikan bagaimana pemanfaatan aplikasi You Tube dan Tik Tok dalam pembelajaran Seni budaya, khususnya pada ranah ekspresi, kompetensi dasar 4.1 Berkarya seni tari kreasi melalui pengembangan gerak berdasarkan konsep, teknik dan prosedur sesuai dengan hitungan. Adapun tujuan dari artikel ini adalah mendeskripsikan proses pemanfaatan aplikasi You Tube bagi guru dalam menyampaikan materi yang dapat di aprsesiasi oleh siswa, dan aplikasi Tik Tok sebagai media berekspresi siswa dalam berkreasi tari. Dengan demikian artikel ini dapat bermanfaat untuk menambah pengetahuan bagi guru tentang pemanfaatan aplikasi You Tube dan Tik Tok secara kreatif dan inovatif dalam proses pembelajaran. Sehingga dapat meningkatkan minat dan motivasi siswa, serta menciptakan pengalaman belajar yang manarik bagi siswa.

\section{METODE PENELITIAN}

Penelitian ini menggunakan metode penelitian kualitatif. Penggunaan metode penelitian kualitatif ini dipilih berdasarkan pada substansi penelitian yaitu menganalisis pemanfaatan aplikasi Youtube dan Tik Tok pada pembelajaran seni budaya. Metode kualitatif dapat menggambarkan keadaan alamiah suatu peristiwa secara holistik dan dinamis yang menekankan pada realitas di lapangan, sehingga data akan berkembang apa adanya dan tanpa adanya manipulasi (Sugiyono, 2016). Dalam penelitian ini penjelasan proses pemanfaatan aplikasi Youtube dan Tik Tok akan didasarkan pada realitas pada saat penelitian dilakukan sehingga data yang diperoleh dapat dipertanggung jawabkan secara ilmiah. Penelitian ini dilakukan di SMA Negeri 1 Kencong Jember, kelas XI MIPA 3, Tahun Pelajaran 2020/2021 semester ganjil. Jumlah peserta didik pada kelas tersebut adalah 35 siswa. Waktu penelitian dilaksanakan pada bulan Oktober 2020, jam pelajaran seni budaya pada materi berkreasi seni tari. Materi ini merupakan bagian dari KD 4.1 Berkarya seni tari kreasi melalui pengembangan gerak berdasarkan konsep, teknik dan prosedur sesuai dengan hitungan.

Penelitian ini dilakukan dengan 3 tahap. Tahap pertama, adalah tahap pembuatan media pembelajaran berupa video yang diunggah pada aplikasi Youtube, yang merupakan pembelajaran ke dalam ranah apresiasi. Tahap kedua, adalah tahap pembelajaran secara luring melalui aplikasi Whatsapp Group, memberikan intruksi kepada siswa terkait pembelajaran berkreasi tari yang akan dilakukan. Tahap ketiga, adalah tahap pembelajaran ranah ekspresi siswa, dimana siswa berkreasi tari menggunakan aplikasi Tik Tok.

\section{HASIL DAN PEMBAHASAN}

\section{Hasil}

Proses pembelajaran ini dilakukan dengan menggunakan model pembelajaran Problem Based Learning (PBL). Penggunaan model pembelajaran PBL bertujuan agar siswa mampu dalam memecahkan masalah yang diberikan dengan melalui krativitas dan proses berfikir 
tinggi.. Tahap proses pembelajaran disesuaikan dengan langkah-langkah estándar proses PBL sehingga nantinya siswa diharapkan mencapai hasil pengalaman belajar yang maksimal. PBL merupakan model pembelajaran yang membebaskan siswa dalam memecahkan masalah yang diberikan. Sehingga siswa dapat mengasah kemampuan berfikir kritis dan mengembangkan ketrampilan serta kemampuan membangun pengetahuan baru sesuai yang dipelajari (Lestari, Slameto, \& Radia, 2018)

Pada awal penelitian tahap pertama yang dilakukan adalah guru membuat perencanaan pembelajaran. Perencanaan tersebut dilakukan dengan membuat Rencana Pelaksanaan Pembelajaran (RPP) yang di sesuaikan dengan keadaan selama masa pandemi, yaitu Pembelajaran Jarak Jauh (PJJ). Pada tahap ini juga sudah ditentukan model pembelajaran yang sesuai dengan keadaan siswa dan lingkungan belajar. Adapun dalam penelitian ini menggunakan model pembelajaran Problem Based Learning (PBL). Sehingga nantinya seluruh kegiatan pembelajaran disesuaikan dengan tahap-tahap pada model pembelajaran PBL. Pada tahap ini guru juga mempersiapkan media pembelajaran berupa video.

Pembuatan video disesuaikan dengan materi yang akan diberikan yaitu berkreasi seni tari. Dalam penelitian ini proses pembuatan video dilakukan oleh guru dengan menggunakan aplikasi pembuatan video Camtasia 2019. Proses pembuatan video dilakukan oleh guru dengan tujuan agar video benar-benar sesuai kriteria yang diharapkan. Adapun kriteria yang diharapkan adalah video bersifat menyenangkan, akan tetapi dapat memberikan pengalaman belajar yang maksimal kepada siswa. Setelah proses pembuatan video selesai, kemudian video pembelajaran yang telah dibuat diunggah pada aplikasi You Tube.

Tahap awal proses implementasi pembelajarannya adalah guru berkordinasi dengan siswa mengenai proses pembelajaran yang akan dilakukan. Guru melakukan koordinasi dengan siswa kelas XI MIPA 3 melalui Whatsapp Group. Pada saat jam pelajaran dimulai, guru memberikan link You Tube yang berisi video pembelajaran yang sudah diunggah sebelumnya. Siswa dihimbau untuk menyimak dan mengamati video yang telah dibuat.

Berikut penjabaran isi dari video yang telah diunggah pada aplikasi You Tube :

1. Pembuka Video

Gambar 1 merupakan pembuka video yang berisi apersepsi tentang pembelajaran mencipta tari yaitu menstimulus siswa dengan kata koreografi dan bagaimana proses koreografi.

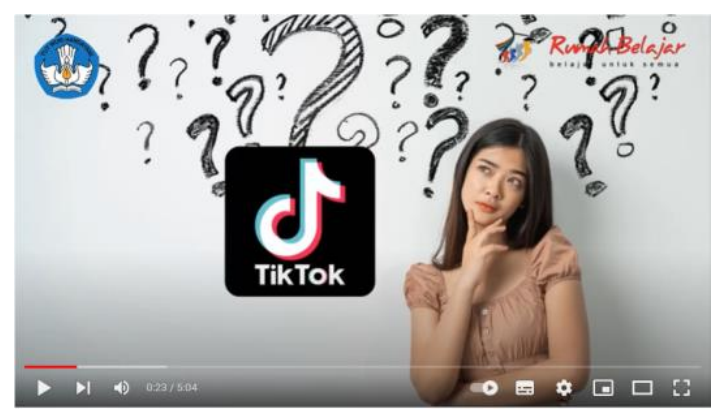

Gambar 1. Pembuka Video (apersepsi)

2. Penyampaian Judul

Pada gambar 2, bagian ini merupakan proses penyampaian judul materi kepada siswa yang bertujuan agar siswa mengetahui materi pembelajaran yang akan dipelajari yaitu berkreasi seni tari : mencipta tari dengan mudah. 


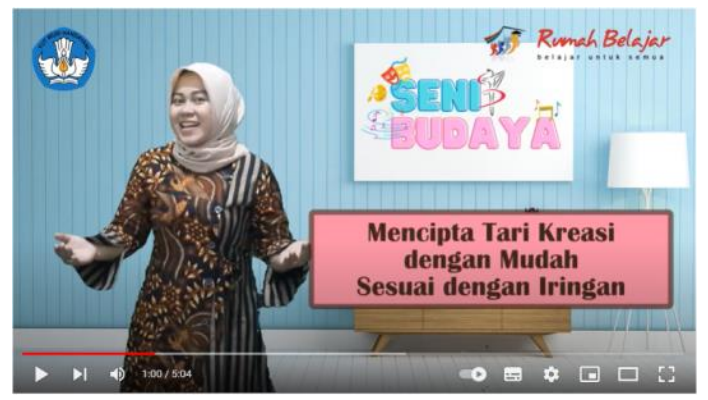

Gambar 2. Penyampaian Judul

3. Penyampaian Tujuan Belajar

Pada gambar 3 video ini merupakan penyampaian dari tujuan belajar yang dilakukan. Bagian ini bertujuan agar siswa mengetahui kompetensi dan indikator yang harus dicapai, yaitu siswa dapat berkreasi dan mencipta tari sesuai dengan kreativitas masingmasing.

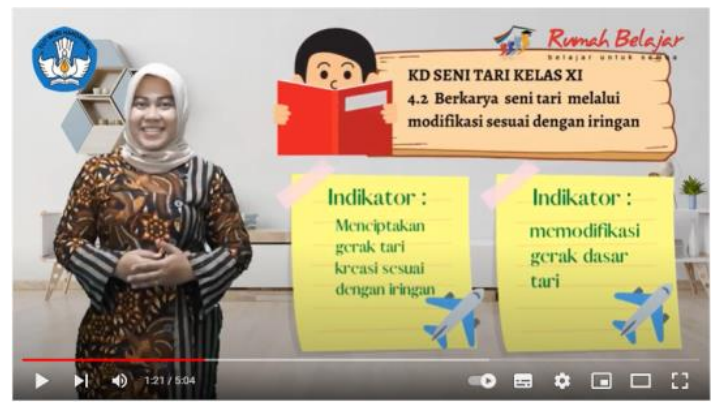

\section{Gambar 3. Penyampaian Tujuan Belajar}

4. Petunjuk Singkat Proses Pembelajaran

Gambar 4 berisi tentang pentujuk bagaimana siswa melakukan proses pembelajaran, sehingga siswa dapat mengikuti proses pembelajaran dengan mudah. Petunjuk singkat ini berisi penjelasan, pertama adalah mengeinformasikan kepada siswa bahawa hitungan dalam tari adalah 1 sampai dengan 8 . Kedua, menginformasikan bahwa siswa dituntut harus percaya diri selama proses pembalajaran berkreasi tari. Ketiga, menginformasikan kepada siswa agar senantiasa berfikir kreatif dan bebas dalam berekspresi gerak tanpa perasaan malu.

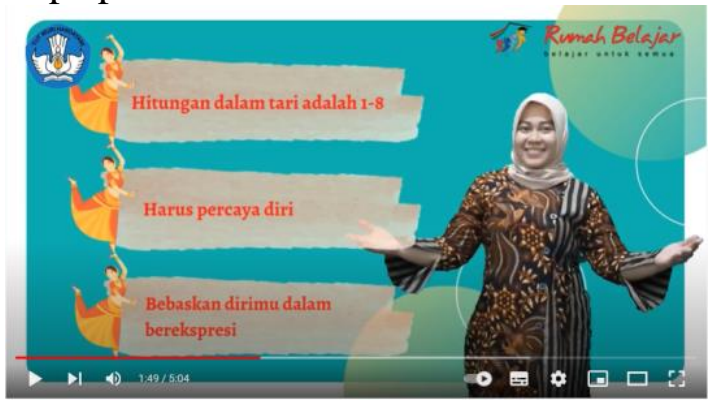

\section{Gambar 4. Petunjuk Singkat Proses Pembelajaran}

5. Penyampaian Materi 1

Pada gambar 5 merupakan penyampaian materi 1. Bagian ini berisi tentang penyampaian tentang tahap awal dalam berkreasi seni tari yaitu memilih iringan musik yang sesuai dengan jenis dan tema tarian atau yang dianggap menarik oleh siswa. Adapun dalam bagian video ini menginformasikan pentunjuk singkat kepada siswa 
dalam memilih iringan musik. Pertama, memilih musik sesuai dengan jenis dan tema tari yang akan dibuat. Kedua, memilih musik yang mempunyai celah dan aksen yang pas untuk diisi dengan gerak tari. Ketiga, memahami dengan baik musik yang dipilih. Memahami musik yang dimaksud adalah mengetahui secara rinci melodi dan ritme dari musik iringan yang dipilih agar pada saat proses eksplorasi gerak menjadi lebih mudah. Penerapannya dalam proses pembelajaran ini, guru menyampaikan kepada siswa agar mencari musik pada aplikasi Tik Tok. Hal ini bermaksud agar proses berkreasi tari menjadi lebih mudah.

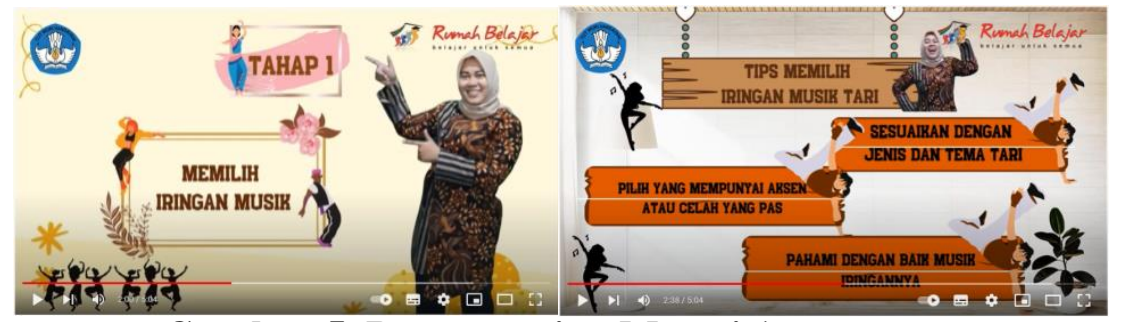

Gambar 5. Penyampaian Materi 1

6. Penyampaian Materi 2

Gambar 6 berisi penyampaian materi 2 berisi tentang proses ekplorasi gerak. Eksplorasi gerak merupakan proses mencari gerak yang akan di rangkai menjadi dalam satu bentuk ragam gerak tari. Dimana apabila sudah terkumpul beberapa ragam yang dirasa sesuai, maka beberapa ragam yamh sudah ditemukan disusun menjadi sebuah tarian. Dalam bagian video ini juga dijelaskan agar siswa melakukan eksplorasi gerak sesuai dengan kemampuan dan kreativitas masing-masing. Sehingga gerak yang dihasilkan adalah gerak yang benar-benar diakuasai oleh siswa dan merupakan hasil eksplorasi murni dari siswa.

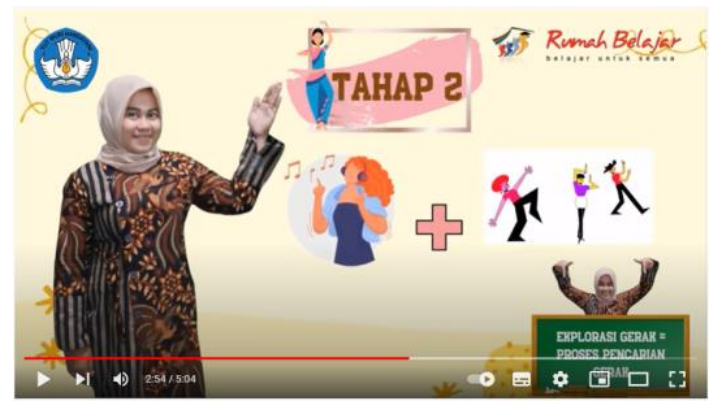

\section{Gambar 6. Penyampaian Materi 2}

7. Penyampaian Materi 3

Gambar 7 berisi penyampaian materi 3 berisi tentang proses evaluasi. Tahap evaluasi merupakan proses melihat kembali hasil gerakan dan tarian yang sudah dirangkai, apakah gerakan tarian yang dirangkai sudah sesuai dengan jenis, tema, dan iringan musiknya. Oleh karena itu tahap evaluasi juga merupakan proses mengurangi, menambah dan mengganti gerakan yang dirasa keruang sesuai. Selain itu proses evaluasi juga merupakan sebuah kunci agar tarian bisa terlihat ritmis dan dinamis. Pada bagian video ini juga dijelaskan kepada siswa untuk merekam hasil dari eksplorasi dan merangkai ragam gerak mengunakan gawai agar proses evaluasi menjadi lebih mudah. 


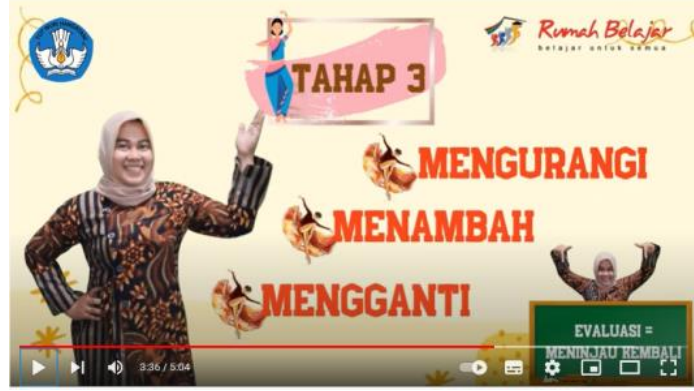

Gambar 7. Penyampaian Materi 3

8. Contoh Proses Pembuatan Tari

Gambar 8 merupakan bagian contoh proses pembuatan tari. Bagian video ini memperlihatkan secara singkat proses mencipta tari dengan mudah. Bagian ini bertujuan agar siswa memiliki gambaran tentang proses dalam mencipta tari. Sehingga siswa akan merasa mudah dalam mempraktekkannya.

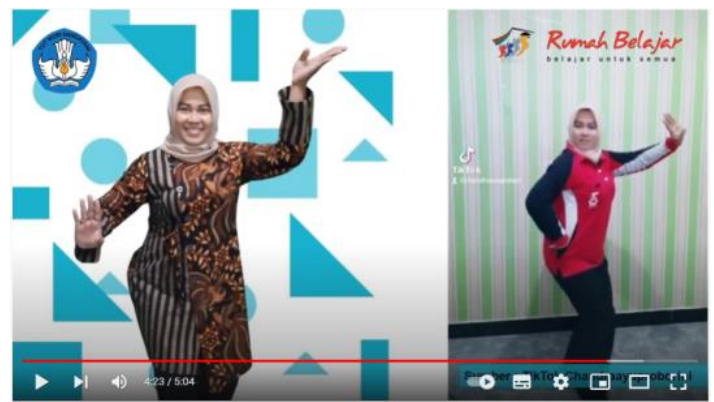

Gambar 8. Contoh Proses Pembuatan Tari

9. Penutup

Gambar 9 merupakan bagian penutup video. Bagian penutup berisi guru memberikan kesimpulan dan motivasi singkat kepada siswa mengenai proses berkarya tari.

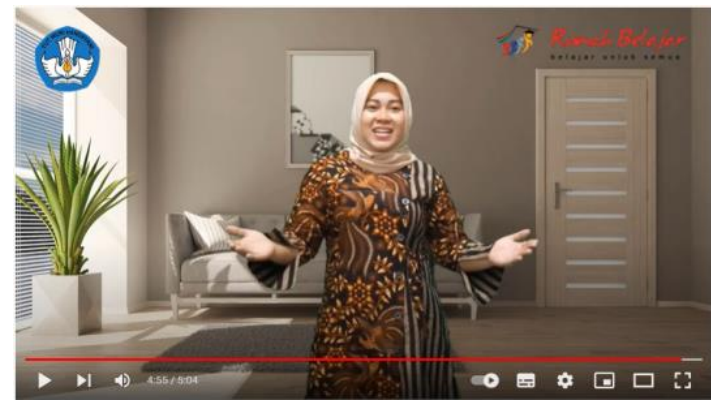

Gambar 9. Penutup

Tahap ke dua proses pembelajaran adalah guru memberikan tugas kepada siswa agar melakukan proses berkarya tari sesuai dengan tahap-tahap yang sudah dijelaskan dalam video yang diunggah pada You Tube. Guru juga menjelaskan bahwa proses pembuatan tarinya menggunakan aplikasi Tik Tok. Selain memberikan tugas, guru juga memberikan pengarahan cara mengumpulkan tugas dan batas waktu dalam mengumpulkan tugas. Adapun cara mengumpulkan tugas adalah dengan mengunggah video hasil kerja siswa pada tautan folder google drive yang sudah dibuat sebelumnya oleh guru. Sedangkan untuk batas akhir pengumpulan video hasil kerja siswa, siswa diberikan tenggang waktu 1 minggu setelah proses menyimak dan mengamati video.Berikut pada gambar 10 di bawah ini merupakan hasil pengumpulan video siswa yang diunggah pada tautan folder google drive. 


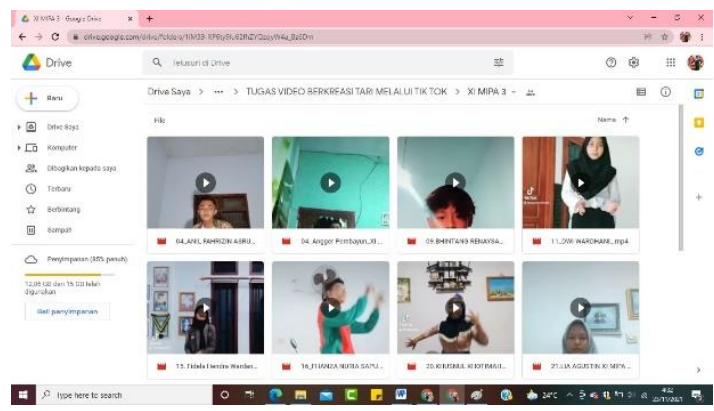

\section{Gambar 10. Folder google drive tempat mengunggah video siswa}

Tahap akhir proses pembelajaran adalah guru melakukan evaluasi proses pembelajaran dan hasil pembelajaran yang dilakukan oleh siswa. Selain itu guru juga memberikan motivasi serta sedikit apersepsi tenatng materi yang akan dipelajari selanjutnya.

Selama proses pembelajaran berlangsung guru memberikan kebebasan kepada siswa untuk berdsikusi dan bertanya kepada sesama siswa maupun guru agar proses pembelajaran dapat maksimal, adapaun proses tanya jawab dan diskusi tersebut dilakukan sacara daring, yaitu melalui Whatsapp Group.

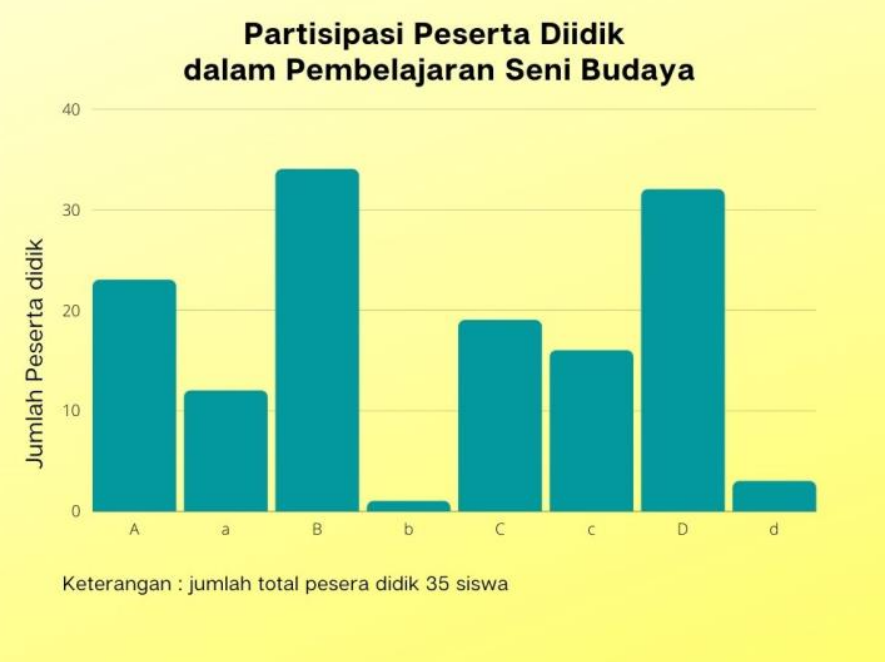

\section{Gambar 11. Grafik peserta didik dalam pembelajaran seni budaya}

Gambar 11 merupakan grafik partisipasi dalam mengikuti proses pembelajaran seni budaya. Adapun penjelasan grafik di atas adalah sebagai berikut ;

1. Batang A merupakan jumlah siswa yang aktif dalam pembelajaran seni budaya sebelum menggunakan aplikasi You Tube dan Tik Tok yang berjumlah 23 siswa

2. Batang a merupakan jumlah siswa yang pasif dalam pembelajaran seni budaya sebelum menggunakan aplikasi You Tube dan Tik Tok yang berjumlah 12 siswa

3. Batang B merupakan jumlah siswa yang aktif dalam pembelajaran seni budaya setelah menggunakan aplikasi You Tube dan Tik Tok yang berjumlah 34 siswa

4. Batang b merupakan jumlah siswa yang pasif dalam pembelajaran seni budaya setelah menggunakan aplikasi You Tube dan Tik Tok yang berjumlah 1 siswa

5. Batang $\mathrm{C}$ merupakan jumlah siswa yang aktif mengumpulkan tugas seni budaya sebelum menggunakan aplikasi You Tube dan Tik Tok yang berjumlah 19 siswa

6. Batang c merupakan jumlah siswa yang aktif mengumpulkan tugas seni budaya sebelum menggunakan aplikasi You Tube dan Tik Tok yang berjumlah 16 siswa

7. Batang D merupakan jumlah siswa yang aktif mengumpulkan tugas seni budaya setelah menggunakan aplikasi You Tube dan Tik Tok yang berjumlah 32 siswa 
8. Batang c merupakan jumlah siswa yang aktif mengumpulkan tugas seni budaya setelah menggunakan aplikasi You Tube dan Tik Tok yang berjumlah 3 siswa

\section{Pembahasan}

Berdasarkan penelitian yang dilakukan, proses pembelajaran yang dilakukan dengan memanfaatkan aplikasi You Tube dan Tik Tok sangat membantu guru dalam melaksanakan kegiatan belajar mengajar selama pandemi. Pada tahap awal penelitian guru membuat perencanaan pembelajaran. Pada proses ini seorang guru dengan kemampuan pedagogiknya membuat perencanaan pembelajaran agar proses pembelajaran berjalan dengan efektif dan efisien. Dengan kemampuan pedagogik tersebut guru dianggap profesional karena dapat merancang sebuah proses pembelajaran yang terukur dan sesuai dengan kompetensi yang diinginkan (Suryadi \& Muslih, 2019). Oleh karena itu pada proses ini secara tidak langsung dapat meningkatkan profesionalitas dan kemampuan pedagogik guru. Adapun yang dimaksud proses meningkatkan profesionalitas dan kemampuan pedagogik guru adalah pada saat guru membuat media pembelajaran video. Dengan membuat media pembelajaran video sendiri, guru dapat menentukan isi materi yang sesuai dengan karakteristik siswa dan keadaan lingkungan belajar sehingga kompetensi dan indikator yang dirumuskan dapat dicapai secara maksimal oleh siswa.

Selain kemempuan pedagogik sorang guru seni budaya selama masa panndemi haruslah bersikap terbuka dengan perubahan. Seorang guru haruslah terbuka dengan sebuah perubahan, utamanya yang berhubungan dengan pendidikan agar guru dapat menentukan langkah pembaharuan atau inovasi yang tepat dalam proses pembelajaran (Roesminingsih \& Susarni, 2016). Dengan sifat terbuka guru akan dapat mengikuti perkembangan karakteristik siswa, sehingga dapat menentukan strategi pembelajaran yang tepat bagi siswa. Perubahan yang biasa terjadi adalah perubahan kurikulum. Adanya perubahan kurikulum yang digunakan menjadi sebuah kewajiban bagi guru dalam memahaminya, sehingga guru akan dapat merancang pembelajaran yang tepat bagi siswa (Kusumastuti, 2010). Selain perubahan kurikulum adapun dalam penelitian ini adalah menghadapi perubahan proses pembelajaran selama masa pandemi, dengan sifat terbuka membuat guru siap siaga dalam menyikapi perubahan yang terjadi, khususnya pada masa pandemi Covid-19. Tentunya hal itu semua bertujuan agar siswa tetap mendapatkan pengalaman belajar yang menyenangkan dengan hasil yang maksimal.

Penggunaan model pembelajaran Problem Based Learning (PBL) merupakan salah satu upaya guru dalam meningkatkan daya berfikir kritis siswa (Lestari, Slameto, \& Radia, 2018). Melalui tahap-tahap yang ada pada model pembelajaran PBL siswa dapat mengembangkan secara bebas ide-ide meraka dalam proses berkarya tari. Karena pada dasarnya PBL tidak menuntut pembelajaran secara terstruktur, sehingga siswa dapat dengan bebas berkreasi dan berinovasi dalam menyelesaikan masalah adapun yang dimaksud dalam hal ini adalah tugas dalam berkarya tari.Selian itu pemilihan model PBL dilandasi dengan indikator yang harus dicapai yaitu siswa dapat berkreasi membuat seni tari. Menurut Amir (2009) model Pembelajaran PBL dapat membantu siswa lebih mengasah ketrampilan siswa dan PBL juga memberikan pengalaman belajar yang bermanfaat kepada siswa sehingga siswa mempunyai kemampuan kecakapan hidup yang melekat pada siswa yaitu memcahkan masalah, bekerja sama dan berkomunikasi dengan baik. Oleh karena itu guru memilih model PBL agar siswa memperoleh manfaat yang kompleks dalam proses pembelajaran. Manfaat tersebut selain didapat dari materi yang diajarkan tetapi juga didapat dari proses belajar. Selain itu, melalui model PBL siswa tidak lagi melalukan pembelajaran berkreasi tari secara imitatif, yaitu pembelajaran tari yang menirukan gurunya seperti pada umumnya. Akan tetapi siswa akan berkreasi tanpa menirukan gerak dari guru. Dalam pembelajaran seni tari yang sifatnya imitatif atau menirukan akan cenderung menghambat kreatifitas siswa (Kusumastuti, 2010). Pernyataan tersebut semakin membuktikan bahwa pemanfaatan media video yang di unggah pada aplikasi You Tube dapat meningkatkan kreativitas siswa. 
Tahap awal proses implementasi pembelajaran merupakan tahap awal guru mengkondisikan siswa agar siswa nantinya dapat melakukan proses pembelajaran yang sesuai dengan perencanaan guru. Pada tahap ini guru memberikan sedikit apersepsi melalui Whatsapp Group tentang materi yang akan disampaikan dan penggunaan aplikasi You Tube dan Tik Tok sebagai sumber belajar siswa. Melalui sedikit apersepsi yang dilakukan ini secara otomatis siswa menjadi antusias dalam menyimak pembelajaran, mengingat bahwa kedua aplikais tersebut merupakan aplikasi yang sedang populer dikalangan remaja. Oleh karena itu hal ini sangat membantu guru untuk melakukan tahap proses pembelajaran selanjutnya.

Tahap proses pembuatan video dilakukan dengan merujuk pada sintaks model pembelajaran PBL. Pada bagian awal video merupakan tahap pendahuluan yaitu apersepsi, yang berisi penyampaian judul materi dan tujuan pembelajaran. Dimana dalam model pembelajaran PBL bagian video ini merupakan tahap yaitu guru memberikan padangan kepada siswa untuk mendasari pemikiran dalam menghadapi masalah, yaitu memberikan pandangan tentang berkarya tari dan proses koreografi. Bagian video selanjutnya adalah memberikan petunjuk singkat proses pembelajaran dan penyampaian materi. Tahap ini dalam model pembelajaran PBL merupakan tahap eksplorasi yaitu mengintegrasikan siswa untuk belajar, pada bagian video ini guru menyampaikan petunjuk teknis berkarya tari dan memberikan masalah yaitu untuk mencipta tari dengan musik iringan dari aplikasi Tik Tok. Peran siswa pada tahap eksplorasi adalah mengikuti petunjuk dan menerima masalah yang guru berikan. Bagian video selanjutnya adalah contoh proses mencipta tari dengan aplikasi Tik Tok dan bagian penutup video berisi motivasi kepada siswa dalam proses belajar mencipta tari. Dalam video hanya berisi 2 sintaks PBL sedangkan 3 sintaks lainya yaitu membimbing pemacahan masalah, menyajikan karya dan mengevaluasi hasil proses dan karya tari dilakukan diluar dari isi video yang tetap dilakukan secara daring, yaitu melalui Whatsapp Group dan tatap muka pada pertemuan selanjutnya melalui aplikasi Google Meet.

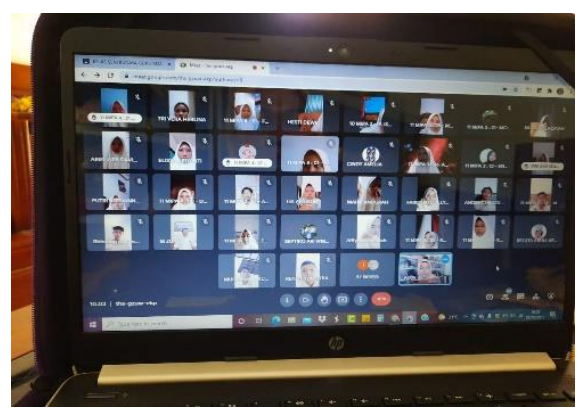

\section{Gambar 11. Bimbingan dalam menentukan musik iringan melalui daring}

Proses PJJ selama pandemi menjadi masalah yang kompleks bagi guru seni budaya yang membutuhkan pembelajaran apresiasi dan ekspresi. Pemanfaatan aplikasi You Tube dan Tik Tok menjadi sebuah alternatif penyelesaian masalah tersebut bagi guru seni budaya selama pandemi. Dalam penerapannya apalikasi You Tube dan Tik Tok dapat menjadi solusi dari permasalahan tersebut, aplikasi You Tube dapat menggantikan kegiatan apresiasi, sedangkan aplikasi Tik Tok dapat menggantikan kegiatan ekspresi. Dalam hal ini guru bertransformasi agar lebih melek digital. Guru harus tau aplikasi dan media sosial terbaru yang sedang populer di masyarakat umum, khususnya dikalangan siswa sekolah menengah. Dalam proses penelitian ini disamping guru juga belajar dalam mengedit video, guru juga mengakses secara aktif aplikasi You Tube dan Tik Tok, hal ini bertujuan agar guru tidak ketinggalan dengan pembaharuan aplikasi dan informasi yang ada pada You Tube dan Tik Tok. Pada penerapannya guru membuat channel video pada aplikasi You Tube dan akun pada aplikasi Tik Tok. Hal ini bertujuan agar guru mengetahui karakteristik aplikasi You Tube dan Tik Tok dan menyesuaikan dengan materi belajar siswa. 


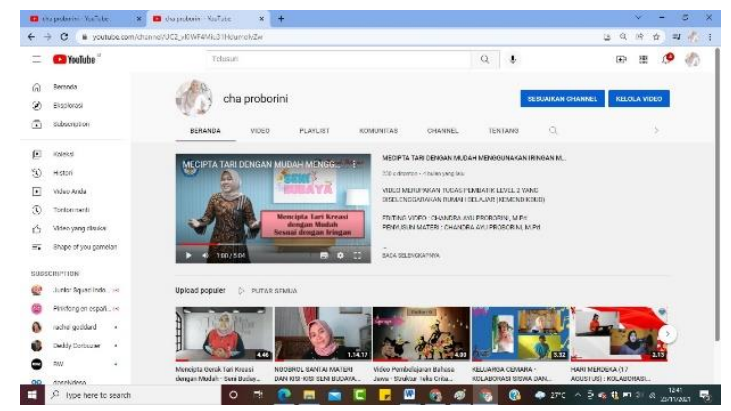

\section{Gambar 11. Akun You Tube Guru untuk mempublikasikan video pembelajaran}

Pemilihan aplikasi You Tube dan Tik Tok didasarkan pada kepopuleran aplikasi tersebut pada usia remaja. Aplikasi You Tube dan Tik Tok menjadi mejadi media bagi guru untuk dapan membuat rancangan pembelajarannya terintegrasi dan selain juga dapat diakses oleh siapa saja yang ingin belajar dimana saja dan kapan saja (Kaplan \& Haenlein, 2010). Pada penerapannya dalam penelitian ini aplikasi You Tube dan Tik Tok membantu guru dalam mengimplementasikan rancangan pembelajarannya secara utuh dan terintegrasi. Selain itu aplikasi You Tube dan Tik Tok dapat diakses dimanapun siswa berada, dan siswa juga dapat melihat kembali video yang diunggah pada aplikasi You Tube dan Tik Tok. Hal ini sangat memudahkan stageholder yang terlibat. Adapun yang dimaksud adalah memudahkan guru sebagai fasilitator yang akan mendampingi siswa dalam belajar, meudahkan siswa dalam mengakses sumber belajar, Kepala sekolah sebagai pengawas keberlangsungan proses pembelajaran dan orang tua siswa yang ingin melihat proses belajar siswa.

Pemilihan media video yang diunggah pada aplikasi You Tube membuat siswa lebih paham dengan materi yang sedang dipelajari. Penggunaan media video pembelajaran dalam tari dapat merangsang siswa untuk memunculkan rasa ingin belajar menari sehingga dengan adanya rasa keinginan tersebut maka akan mudah dalam menciptakan pengalaman bagi siswa dalam berkreasi tari (Dewika, Yuliasma \& Iriani, 2013). Sesuai dengan pernyataan tersebut dengan adanya media video, selain siswa dapat dengan mudah menyerap materi, akan tetapi siswa juga secara tidak langsung dapat merangsang siswa untuk melakukan gerak tari baik itu meniru maupun menciptakan. Oleh karena itu penggunaan media video yang diunggah pada aplikasi Yои Tube menjadi strategi yang sesuai dalam pelajaran seni budaya dengan materi berkreasi seni tari.

Pada penelitian proses pembelajaran ini, peserta didik memberikan respon yang baik, hal ini dibuktikan dengan seluruh siswa di kelas XI MIPA 3 menyelesaikan permasalahan dan tugas yang diberikan dengan baik. Peserta didik merasa bahwa pengemasan materi yang diberikan oleh guru kepada siswa sangatlah mudah dimengerti dan mudah diaskses kapan saja dan dimana saja siswa ingin mengakses. Selain itu siswa juga antusias dalam mengerjakan tugas dengan kreatif karena tugas yang diberikan berbatuan dengan aplikasi Tik Tok yang sedang populer dikalangan anak usia remaja. Dengan demikian proses pembelajaran ini selain siswa dapat mencapai indikator yang ditentukan guru dampak lain adalah meningkatnya kreativitas siswa melalui pembelajaran berkarya tari. Hal ini sesuai dengan pernyataan bahwa pembelajaran seni yang pengelolaannya baik maka akan memberikan dampak yang positif terhadap kreativitas siswa, oleh karena itu penentuan strategi pembelajaran yang tepat menjadi salah satu kunci keberhasilannya (Kusumastuti, 2010). Adapun kendala dalam penelitian proses pembelajaran ini adalah membimbing siswa yang merasa kurang percaya diri dalam berekspresi gerak. Dalam hal ini guru sebagai fasilitator memberikan bimbingan secara khusus kepada siswa yang memiliki rasa percaya diri yang kurang melalui aplikasi Whatsapp, baik itu melalik pesan ataupun telepon video. 


\section{KESIMPULAN}

Pemanfaatan aplikasi You Tube dan Tik Tok sangat membantu proses pembelajaran seni budaya selama masa pandemi. Adanya aplikasi ini menjadi alternatif bagi guru dalam melakukan pembelajaran dalam ranah apresiasi dan ekspresi. Selain itu dengan pemanfaatkan aplikasi You Tube dan Tik Tok juga sangat menarik minat para siswa dalam proses belajar, sehingga memberikan pengalaman belajar yang menyenangkan bagi siswa. Adapun manfaat dalam pemanfaatan aplikasi ini sangat kompleks. Dari perspetif siswa, siswa dapat menyerap materi dengan mudah dan meningkatkan ketrampilan dan kecakapan dalam memecahkan masalah dan berkomunikasi dengan baik. Sedangkan dari perspektif guru, selain dapat meningkatkan kemampuan guru dalam menguasai teknologi dan informasi, akan tetapi secara tidak langsung juga dapat meningkatkan kemampuan pedagodik guru. Adanya penelitian ini diharapkan nantinya dapat menginspirasi para guru agar selalu berinovasi dalam melakukan proses pembelajaran sehingga dapat melakukan proses pembelajaran selama pandemi dengan mudah. Dengan demikian dapat memberikan pengalaman belajar yang menyenangkan dan mencapai target indikator yang sudah ditentukan.

\section{DAFTAR PUSTAKA}

Amir, M.Taufiq. (2009). Inovasi Pendidikan melalui Prolem Based Learning: Bagaimana Pendidik Memberdayakan Pemelajar di Era Pengetahuan. from

Dewika, Pebrina., Yuliasma \& Iriani, Zora. (2013). Strategi Guru dalam Mengembangkan Kreativitas Siswa pada Pembelajaran Seni Tari di SMA Negeri 3 Payakumbuh. EJurnal Sendratasik FBS Universitas Negeri Padang, Vol. 2 No. 12013 Seri B, from doi: http://ejournal.unp.ac.id/index.php/sendratasik/article/view/2279

Fanaqi, Chotijah. (2021). Tiktok Sebagai Media Kreativitas di Masa Pandemi Covid-19. Jurnal Dakwah. Vol. 22 No. 1, from doi: http://ejournal.uinsuka.ac.id/dakwah/jurnaldakwah/article/view/1978.

Kaplan, Andreas dkk. (2010). Users of the world, unite! The Challenges and Opportunities of Social Media Kelley School of Business Business. Horizons. Vol. 53 No. 1,

Kusumastuti, Eny. (2010). Pendidikan Seni Tari Melalui Pendekatan Ekspresi Bebas, Disiplin Ilmu, dan Multikultural sebagai Upaya Peningkatan Kreativitas Siswa. Jurnal Harmonia, Vol. 10 No.2,

Lestari, Y., Slameto, \& Radia, E. (2018). Penerapan Pbl(Problem Based Learning) Berbantuan Media Papan Catur Untuk Meningkatkan Hasil Belajar Matematika Kelas 4 SD. Jurnal Pendidikan Dasar PerKhasa, 4(1), 53-62, from doi: https://media.neliti.com/media/publications/271621-penerapan-pblproblem-basedlearning-berb-acb5af94.pdf

Roesminingsih, MV., Susarno, Lamijan Hadi. (2005). Teori dan Praktek Pendidikan. Surabaya: Lembaga Pengkajian dan Pengembangan Ilmu Pendidikan FIP UNESA

Sari, Lurita. Upaya Menaikkan Kualitas Pendidikan dengan Pemanfaatan Youtube sebagai Media Ajar pada Masa Pandemi Covid-19. Jurnal Tawadhu Vol. 4 no. 1, 2020, from doi : https://ejournal.iaiig.ac.id/index.php/TWD/article/viewFile/226/163

Sugiono. (2016). Metode Penelitian Kuantitatif, Kualitatif, dan R\&D. Bandung: Alfabeta 